\title{
TALISMANIC PRACTICE AT LEFKANDI: TRINKETS, BURIALS AND BELIEF IN THE EARLY IRON AGE
}

\author{
Nathan T. Arrington ${ }^{\star}$ \\ Princeton University, USA
}

Excavations at Lefkandi have dispelled much of the gloom enshrouding the Early Iron Age, revealing a community with significant disposable wealth and with connections throughout the Mediterranean. The eastern imports in particular have drawn scholarly attention, with discussion moving from questions of production and transportation to issues surrounding consumption. This article draws attention to some limitations in prevalent socio-political explanations of consumption at Lefkandi, arguing that models relying on gift-exchange, prestigegoods and elite display cannot adequately account for the distribution, chronology, find context and function of imports at Lefkandi. A study of trinkets - small but manifestly foreign imports of cheap material - offers a new perspective. An analysis of their form, context, use and meaning demonstrates that trinkets were meaningfully and deliberately deposited with children as talismans or amulets. Talismanic practice had Late Bronze Age precedents, and in the Early Iron Age was stimulated from personal contact with the Near East or Cyprus and nurtured by the unique mortuary landscape at Lefkandi. This article demonstrates the need for archaeologists to treat mortuary beliefs as a meaningful explanatory variable. Moreover, the ability of non-elite objects to convey powerful ideas has important implications for the nature and dynamics of artistic and cultural exchanges between Greece and the East in the Iron Age.

\section{Introduction}

Archaeologists and historians are still coming to terms with the remarkable discoveries in the 1980 os and I9gos at the cemeteries of Lefkandi in Euboea. ${ }^{\mathrm{I}}$ An enormous apsidal building, elaborate and costly burials of a man and a woman inside the structure and a cemetery teeming with imports were among the startling finds that made the

* Email: nta@princeton.edu

I I am thankful to John K. Papadopoulos and Joanna S. Smith for their comments on earlier versions of this manuscript. Any errors that remain are my own. 
post-palatial period characterised as a Dark Age glow. ${ }^{2}$ This Protogeometric (PG) community had mastered such skills as bronze casting and gold working, and was connected to a wide world that extended from Italy to Macedonia to Cyprus and beyond. ${ }^{3}$ Not only did it import precious minerals and valuable metal vases, but it exported goods as well, probably silver and/or grain. ${ }^{4}$ Euboean pottery (including trade amphorae) found on Cyprus and in the Levant, as well as the identification of a shared ceramic koine covering Boeotia, Phokis, East Lokris, Thessaly, Skyros and some of the Cyclades, testify to the island's strength and influence. ${ }^{5}$ It was one of the first and most active participants in a widening Mediterranean world, a well-connected hub in a growing network. ${ }^{6}$

The quantity and variety of imports and metalwork, especially from the Toumba cemetery located at one end of the apsidal building, offered a richness unmatched anywhere else in the Aegean at such an early date. Scholars at first addressed questions related to production and distribution - where the objects were made and who transported them - with debates over the origin of various goods and over eastern versus Greek trade initiatives in the Aegean, debates which remain rather inconclusive. ${ }^{7}$ More recently, and more productively, scholars have discussed the consumption of imports, with particular concern for their role in shaping and negotiating local social and political dynamics within a community emerging from the disruption and poverty that followed the Late Bronze Age. ${ }^{8}$ To varying degrees, it is the role of the elite that has been

2 The principal publications are Popham, Sackett and Themelis 1979-80; Popham, Calligas and Themelis I993; Popham and Lemos 1996 (plates only); Evely 2006. Preliminary reports on more recent work on the settlement have appeared in AR 50 (2004) 39-40, 5I (2004-5) 50-2, 52 (2005-6) 62-3, 53 (2006-7) 38-40, 54 (2007-8) 5I-4, 55 (2008-9) 47-9; Lemos (2007), (2012) 22-4.

3 The following abbreviations are used for chronological periods:

LH IIIC, Late Helladic IIIC, c. II90-I050 BC

EPG, Early Protogeometric, c. I050-1000 BC

MPG, Middle Protogeometric, c. Iooo-950 BC

LPG, Late Protogeometric, c. 950-900 BC

SPG I, Sub-Protogeometric I, c. 900-875 BC

SPG II, Sub-Protogeometric II, c. $875-850$ BC

SPG III, Sub-Protogeometric III, c. $850-825$ BC

MG, Middle Geometric, c. $850-760$ BC

LG, Late Geometric, c. 760-70o BC

CG I, Cypro-Geometric I, c. I050-950 BC

CG II, Cypro-Geometric II, 950-850 BC

CG III, Cypro-Geometric III, 850-750 BC

Silver: S. P. Morris (1992) 139. Grain: Descoeudres (2008) 316-I8.

5 Exports: most recently, Coldstream (2008). Ceramic koinē: Lemos (200I), (2002) 2I2-I7; Mazarakis Ainian (20I2) 83-9, arguing that more cultural traits were shared than ceramics alone. Contra, Papadopoulos (20II) I27-8.

6 On networks see esp. Malkin (20II).

7 Euboean initiative, e.g. Popham (I994) 28-30; Lemos (2005). Phoenician initiative, e.g. Perreault (I993); Kuhrt 2002. The debate is cogently reviewed in Descoeudres (2008) 315-17.

8 Antonaccio (2002); Crielaard (I993), (1998), (2006); I. Morris (2000) 195-256. On the study of consumption see Foxhall (I998) 297-8 and passim. On the role of the Assyrians see Frankenstein (1979); Sherratt and Sherratt (I993); and the critique in Fletcher (2012). 
emphasised in acquiring, using and disposing of imports qua prestige-goods. ${ }^{9}$ At the risk of over-simplifying diverse and nuanced perspectives, the prevailing model may be briefly summarised. Imports from the east - exotica, such as a Cypriot bronze ash urn in the apsidal building or Cypro-Phoenician bowls - were acquired through exchanges dominated by the elite and contingent on personal relationships at the highest levels of society: marriage or, more frequently, gift-exchange. ${ }^{\text {Io }}$ Next, the distribution and circulation of the imports were controlled, restricted and rationed. Finally, and following from the first two points, the exotica as prestige-goods were displayed to distinguish a group of elite, to join an international group of elite, or to compete among the Lefkandi elite; they were gifted in order to acquire prestige through generosity; or they were removed from circulation to increase their value. Thus, this perspective maintains, longdistance imports were both a cause of increased social complexity and a means for the elite to secure and preserve status. ${ }^{\text {II }}$

Lefkandi has helped to forge the perception of a symbiotic relationship between eastern exotica and elite status that scholars maintain continued through the Orientalising period (late eighth and seventh centuries) and beyond. ${ }^{\text {I2 }}$ Ian Morris's claim that ' $\left.\mathrm{t}\right] \mathrm{he}$ orientalizing movement was a class phenomenon', encapsulates, albeit in unusually explicit language, pervasive perceptions of the relationships between Greece and the East, whereby a vaguely defined geographical sphere becomes synonymous with luxury and a source of external authority and power. Perhaps the fact that current approaches to Lefkandi fit so neatly within this discourse should alert us to the need to take a second look. Understanding what happened at Lefkandi at the time when contact between the Aegean and the Near East was resuming is a critical first step in assessing the many factors underlying Mediterranean cross-cultural dynamics.

This paper offers a new perspective on the grave assemblages at Lefkandi and, more broadly, on exchange and consumption in the Early Iron Age, by focusing not on highstatus imports but on trinkets. ${ }^{\mathrm{I}} \mathrm{A}$ trinket is here defined as a small object, of manifestly

9 On the concept of prestige-goods see esp. Friedman and Rowlands (1977). Gosden (I985) offers an important analysis of the model and a critique of its applicability to Iron Age Europe. In addition to the works in note 8 above, other studies that emphasise the role of the elite include Lemos (2002) I68; Niemeyer (2003), discussing Phoenician trade in general; Walker (2004) 82-3; Gunter (2009), on Orientalising more generally.

Io Literature on gift-exchange draws inspiration from Homer, who provides an authoritative if poetic voice for the role of personal relationships in the movement of objects in pre-capitalist societies: Finley (2002 [I954]) 62-8; van Wees (1992) 222-37; Satlow (2013).

II Cf. Helms (I993) on the power of foreign skills and objects.

I2 On the dynamics of exchange in the Orientalising phenomenon, e.g. Boardman (200I) 36 .

I3 I. Morris (2000) I84: 'The orientalizing movement was a class phenomenon. Desire for eastern rites, dress, perfumes, images, and utensils was political. Those who adopted them pretended that they belonged to a grander and better world than the ignorant peasants around them.'

I4 Antonaccio (2002) recognises that the model of gift-exchange cannot explain all the goods at Lefkandi, and she envisages incidental trade accompanying high-status trade (pp. I6-I7). Papadopoulos (I997), also aware of the limits of prevailing models, rhetorically asks, '[W]as the Phoenician alphabet adopted by the Greeks as part of a gift-exchange?' (p. 200). On the limitations of gift-exchange see also Foxhall (1998) 300. In a discussion of Phoenician trade and the variety in quality of goods, Winter (I995) posits different quality products aimed at 
foreign origin, neither locally produced nor even locally imitated, and made of relatively inexpensive material. For example, a faience scarab is a trinket. It was small enough to be worn around the neck or wrist, and its details were only discernible from up close. The form had Egyptian and Near Eastern parallels, and inscribed hieroglyphs reinforced its otherness and rendered it manifestly non-local. Moreover, neither local production nor local imitation of this type of object existed on Euboea, suggesting that the object's distant origin was essential to its ontological status and to its meaning. A local copy, that is, could not serve as a substitute. ${ }^{15}$ Finally, as will be discussed in more detail below, faience was relatively inexpensive. Some counter-examples may help to define further the category of trinket. A clay bead may be small and made of a widely available material, ${ }^{\mathrm{I} 6}$ but it was not sufficiently foreign in terms of origin, form or iconography to be classified as a trinket. Conversely, an engraved bronze bowl could evoke distant lands, ${ }^{17}$ but was produced on a scale that made the object easily visible, and out of a material widely acknowledged to be valuable. In ancient Greek, the appropriate word for trinkets might be athurmata, associated with frivolity and childish play and on one occasion described by Homer as the cargo of 'greedy and deceitful' Phoenicians. ${ }^{18}$ There are a number of possible synonyms for 'trinket' in English: bibelot, gewgaw, bauble, doodad or curio. With different connotations, all refer to minor exotica: on the one hand, somewhat wondrous and unusual; on the other, somewhat cheap. Relatively neglected in the scholarly literature, the ambiguity and potential contradiction of trinkets makes them an interesting subject for study.

The paper first considers whether trinkets as imports can be integrated into models of elite consumption at Lefkandi. The discussion does not attempt to be comprehensive, but draws attention to some of the limitations of socio-political explanations of consumption at this site. In addition, it underscores the extreme variability and heterogeneity in the grave assemblages, and concludes that there was no established language of elite display and no consistent rationing of imported goods. Thus divorced from any simple equation with the consumption of eastern exotica, the trinkets require a close analysis of their form, context, use and meaning, which is the subject of the next section. This analysis, which draws on comparanda from around the Mediterranean, suggests that non-rational belief in the protective power of trinkets rather than utilitarian socio-political aims best explains their selective use and deposition. Three interrelated causes or conditions for the existence of this belief are then examined. The article concludes by considering the

different markets and audiences (pp. 252-3). Gunter (2009) provides an interesting discussion on trinkets, but ultimately emphasises their elite contexts and distant origins rather than their 'curio' status (pp. I40-2).

I5 Imports can be contextualised into local practices (e.g. Panagiotopoulos (20I2)), but it is the persistent otherness of trinkets that is notable.

I6 Popham and Lemos (I996) Plate 85.

I7 Popham and Lemos (I996) Plates I33-4.

I8 Hom. Od. I5.4I5-I6. Perceptions of Phoenicians in Homer: Winter (I995); Sherratt (2010) I26. 
broader implications of this study for the social structure at Lefkandi and for connections between the Aegean and the East in the Iron Age.

\section{Socio-political approaches to Lefkandi}

Archaeologists began to focus predominantly on socio-political explanations for variation in mortuary practices in the I970s. ${ }^{\text {I9 }}$ Arthur Saxe (1970) and Lewis Binford (I97I) gave impetus to the turn to assessing the structure and organisation of cultural groups and the rank and status of individuals through an examination of funerary rites and land use. ${ }^{20}$ Such approaches sought to demonstrate how burials could mirror the scope and extent of the relationships of the living with the dead and reflect social complexity. The subsequent post-processualist critique was directed more against the processualist assumptions, methods and universalising cross-cultural aims than against their goal of explaining change and variation in light of social relationships. These critiques pointed out that mortuary rituals do not reflect but rather construct, negotiate and contest social and political identities and ideologies, and they highlighted the enormous variability to mortuary rituals that processualist approaches could not satisfactorily explain. Cemeteries were places where agents (collective and individual) could use material goods and social practices to transform as well as to replicate norms. But despite the new interpretive paradigms, socio-political concerns have remained paramount, and the elite and elite goods have played the predominant role. ${ }^{2 \mathrm{I}}$

Yet the application of socio-political models of consumption to Lefkandi, particularly those involving conceptions of prestige-goods, gift-exchange and elite display, raises several problems, which can be organised under four rubrics: (I) geography, (2) chronology, (3) find context and (4) the interpretation of specific goods.

(I) After several decades, Lefkandi remains exceptional in its regional context. Imported goods appear nowhere else on or near mainland Greece in such quantity at such an early period. The discrepancy is startling and defies ethnographic parallels. We may perhaps imagine that an elite at Lefkandi prevented local non-elite from consuming exotica, causing variation between Toumba and the other cemeteries at Lefkandi; but how did they prevent nearly every other city in mainland Greece? The situation is particularly paradoxical because if the goods were circulated through gift-exchange, as is often maintained, then members of the elite should have been gifting prestige items at the regional level and beyond, causing a more diffuse distribution pattern. Not only would we

I9 Reviews of archaeological approaches to the mortuary record: Chapman and Randsborg (I98I); Bartel (I982); Chapman (I987) and (2013); Whitley (I991a) 23-34; Parker Pearson (I999) esp. 72-94; David and Kramer (200I) 378-408; Rakita and Buikstra (2005); Ames (2008) 497-500. Whitley (I991a) and I. Morris (I987) have investigated the relationship between burials and social structure in Early Iron Age Greece.

20 See also Tainter (1975) and (1978); Goldstein (1976) and (I981).

2I Classic examples of the post-processualist approach are Hodder (I980); Parker Pearson (I982); Shanks and Tilley (I982). On agency: Dornan (2002). 
expect gift-exchange among the elite to spread luxury goods further than the confines of Lefkandi, but peer-polity interaction and competition should have compelled other elite to emulate the consumption and display at Lefkandi, and thus to seek exchange from Lefkandi elite or from their trading partners, who would have been eager to acquire more goods and to develop more contacts. ${ }^{22} \mathrm{~A}$ contrast might be helpful here: in Iron Age Europe, sometimes invoked as comparandum for Lefkandi, imports were concentrated at several Late Hallstatt centres, and multiple cemeteries contained burials that could be ranked according to a shared symbolic system. ${ }^{23}$ This pattern contrasts with the regional isolation of Lefkandi and, as we will see, with the variety of grave goods within its cemeteries.

Perhaps Lefkandi simply was remarkably isolated from the rest of the Aegean. Yet the imports and the ceramic koine point to connectivity, and the tradition of an Archaic Lelantine War, whether true in detail or not, suggests that at least by the seventh century, more than one Euboean community was sufficiently competitive to fight, and sufficiently interconnected to obtain allies from far and wide. ${ }^{24}$ The geographic location of Lefkandi further suggests that connectivity was an important part of its function, for it was not the first landing point for a trader coming from the east, but it was an excellent stopping point for anyone going north, up the strait, or west, to the mainland.

(2) Although the graves at Lefkandi, with a few exceptions, disappeared after c. 825 and the record of imported exotica ceased, Euboean goods continued to appear in the east, and in greater quantity. ${ }^{25}$ An engine of exchange - elite funerary consumption - seems to have disappeared, and yet exchange intensified.

(3) Few explanations of exotica at Lefkandi address their nearly exclusive appearance in graves. Instead, the burial assemblages of the dead are used to reconstruct the status of the living, which is a perilous interpretive leap. ${ }^{26}$ The assumption is that as people became richer, they deposited more in graves. In order to calculate social stratification on the basis of tombs, one needs a larger sample, and one needs settlement evidence. It is particularly important to know if production was closely associated with the elite.

The graves themselves are more diverse than might be expected for one wealthy family, as is often maintained, including shafts lined and unlined, trench-and-hole burials and

22 Cf. the Kongo and the Portuguese, the paradigm of prestige-exchange: 'Unfortunately for the Kongo king the monopoly over trade, which formed the basis of his power, was directly counter to the Portuguese interests. The Portuguese were engaged in commercial trade and wanted to encourage competition amongst their clients in order to ensure the highest prices for their goods' (Gosden (I985) 477).

23 Wells (I980) 49; Pare (I992) 202-4. Used as comparandum for Lefkandi: Antonaccio (2002) I9-20.

24 Lelantine War: Parker (1997). Some scholars believe that Lefkandi was old Eretria. See the discussion in Popham, Sackett and Themelis (1979-80) 423-4.

25 Only two LG graves have been found (Lemos (2007)), but settlement continued into the eighth and early seventh centuries.

26 Niemeyer (2003) is unusually explicit: 'It may be assumed that it made no difference whether the keimelia - to use the Homeric term - were displayed in the private treasury or they formed part of the tomb furniture at the funeral or served to demonstrate the pride and munificence of an aristocratic dedicant. In all these cases, first and foremost, they would have served to highlight the owner's or donor's prestige, to buttress his élite status' (p. 205). 
double burials. Important new understanding of the burial rituals further contributes to the picture of pronounced variation both in burial type and in the economic status of the burying groups. Although the first excavators thought that the dead were cremated and a token of their ashes placed in a grave, we now know that the deceased in the shafts were inhumed, but their bones decayed and left little to no trace. ${ }^{27}$ This means that the cremation pits in Toumba were primary burials, and most of them were very poor in terms of grave goods: of the thirty-five pyres, twelve were empty, and seven contained only one or two objects. ${ }^{28}$ One reason for this variation may be a lack of formal planning, for the burial ground had no clearly defined border.

(4) All foreign items tend to be considered of equal value: an import is an import. The application of statistical approaches in particular risks flattening out meaningful distinctions among objects by conflating several different items into one analytic category. Considering a gold earring equivalent to gold foil, for instance, makes possibly inaccurate assumptions about value. ${ }^{29}$ The variety and not just the quantity of exotica at Lefkandi needs explanation. Indeed, the range of goods far exceeds the norm in societies where elite goods are rationed. For contrasts in the ethnographic record, we can look to nineteenthcentury Nuristan (Afghanistan), where elite symbols were rationed and higher-rank items were formally similar to lower-rank items, but more elaborately wrought and crafted of more valuable material. For instance, the number of bells on a wooden bowl or the number of iron bars on a table depended on rank. ${ }^{30}$ This type of ranking does not occur at Lefkandi.

Not only are imports at Lefkandi often considered of equal value, but they are usually associated with the elite. Did such a clear semantic distinction exist? Quantitative and statistical approaches unfortunately do not offer a reliable method for analysing rank in the Lefkandi assemblage because of the relatively small number of tombs, the lack of osteological data, and the absence of well-published settlement evidence. A more qualitative approach, however, can be used to assess the extent to which eastern imports were rank indicators at Lefkandi. There are, it should be emphasised, many ways to evaluate the status of a burial, such as location, size or type; one measure is the quantity of grave goods, with a higher number of goods indicating higher rank. ${ }^{3 \mathrm{I}}$ So one might expect the quantity of grave goods to correlate with the presence of eastern imports. Yet in every period represented at Lefkandi following the construction of the apsidal building, there were, on the one hand, tombs with few grave goods, but an eastern import; and on the other hand, tombs with many grave goods, but few if any eastern imports (see Table I). (It is necessary to include graves from all Lefkandi cemeteries in this discussion, because rank indicators should, by definition, be meaningful throughout the community.)

27 Popham, Sackett and Themelis (I979-80) 2II-I4, revised in e.g. Lemos (2002) I6I-2.

28 Ian Morris (I987) suggested that the pyres could be examples of 'informal burial' (I07-8).

29 E.g. I. Morris (1987) I4I. On value see the essays in Papadopoulos and Urton (2OI2).

30 Jones (I974) I82-5.

3I Carr (I995) I57. 
Table I: Selection of graves at Lefkandi with low numbers of grave goods but including eastern imports, and with high numbers of grave goods but without eastern imports.

\begin{tabular}{|c|c|c|c|}
\hline Period & Grave number & Grave goods & Eastern imports \\
\hline LPG & Toumba Tomb I4 & $\begin{array}{l}2 \text { cremation amphorae, I iron and bronze } \\
\text { spearhead, I iron sword }\end{array}$ & I faience bead \\
\hline LPG & Palia Perivolia Tomb 3 & $\begin{array}{l}24 \text { vases (in tomb and above cover slabs), } \\
\text { bronze and iron pins and fibulae, clay } \\
\text { beads }\end{array}$ & o \\
\hline SPG I & Skoubris Tomb 5 & I cremation amphora, I small amphora & I macehead \\
\hline SPG I & Palia Perivolia Tomb 39 & 22 vases, 2 iron fibulae & o \\
\hline SPG I & Toumba Tomb 3 & $\begin{array}{l}\text { I sea shell, I knife (iron, bronze, ivory), I } \\
\text { bronze fibula, } 2 \text { gold attachments; shaft } \\
\text { above: } 5 \text { vases, I donkey or mule rhyton, } \\
\text { I headless centaur figurine }\end{array}$ & o \\
\hline SPG II & Palia Perivolia Tomb 2I & $\begin{array}{l}\text { Io vases, of which I was Attic, I bronze } \\
\text { dress pin }\end{array}$ & I faience necklace \\
\hline SPG I-II & Toumba Tomb 52 & 2 vases, 2 gold rings, I iron pin & $\begin{array}{l}4 \text { faience pendants, } \\
\text { I2 faience beads }\end{array}$ \\
\hline SPG II & Toumba Tomb 23 & I3 vases & o \\
\hline SPG II & Skoubris Tomb 33 & $\begin{array}{l}\text { I3 vases, bronze and iron pins and fibulae, } \\
\text { I gold earring }\end{array}$ & o \\
\hline $\begin{array}{l}\text { SPG II- } \\
\text { IIIa }\end{array}$ & Toumba Tomb 78 & 4 vases, 9 gold attachments and bands & $\begin{array}{l}\text { I neck of a bronze } \\
\text { vase }\end{array}$ \\
\hline SPG пIIa & Toumba Tomb 32 & $\begin{array}{l}\text { o vases, } 6 \text { bronze fibulae, } 5 \text { gold finger } \\
\text { rings, I gold hair spiral, gold foil, } 2 \text { gilt } \\
\text { pins with amber }\end{array}$ & I faience pendant \\
\hline
\end{tabular}

For example, in LPG, Toumba Tomb I4 contained two cremation amphorae, an iron and bronze spearhead, an iron sword and a faience bead..$^{32}$ This tomb may be contrasted with Palia Perivolia Tomb 3, which contained twenty-four vessels, bronze and iron pins and fibulae, and clay beads. ${ }^{33}$ Both were shaft graves of the same depth (I.30 m). The first had few grave goods but a faience bead that must be an eastern import, while the second had comparatively many more vessels and metal, but no eastern goods. Such contrasting burials can be found in almost every period. In SPG I, Skoubris Tomb 5 contained a cremation amphora, another small amphora and an imported macehead inside the cremation amphora, with all its connotations of power and authority. ${ }^{34}$ In contrast, Palia Perivolia Tomb 39 held five pots and two iron fibulae, with an associated deposit on a shelf above one end of the tomb with seventeen vessels, but no valuable imports. ${ }^{35}$

32 Popham, Sackett and Themelis (I979-80) $175-6$.

33 Popham, Sackett and Themelis (I979-80) I4I-3.

34 Popham, Sackett and Themelis (I979-80) IIO-II.

35 Popham, Sackett and Themelis (1979-80) I56-7. 
Similarly, Toumba Tomb 3 contained a sea shell, a knife, a bronze fibula and two gold attachments, and, in the shaft above the burial, five vases, a donkey or mule rhyton, as well as the famous wheel-made centaur figurine (here headless)..$^{36}$ These last offerings are unusual, but the gold items are probably of local manufacture, and though the knife contains ivory, the knife itself is probably of local or regional origin. ${ }^{37}$ None of the objects is an import like the macehead in Skoubris Tomb 5, there found with little else. In SPG II, Palia Perivolia Tomb 2I contained ten vases, of which one was Attic, one bronze dress pin and an imported faience necklace. ${ }^{38}$ Toumba Tomb 52 (SPG I-II) similarly had few items with only two vases, two gold rings and one iron pin, but a large quantity of faience (four pendants and twelve beads). ${ }^{39}$ At the other end of the spectrum, one may point to Toumba Tomb 23 , with thirteen vessels, but nothing else, ${ }^{40}$ or Skoubris Tomb 33, with thirteen vessels (one a possible Cretan import), bronze and iron pins and fibulae, and one gold earring unrelated to the Cypriot or Levantine repertoire. ${ }^{4 \mathrm{I}}$ Only in SPG IIIa were imports more widespread than before, and tombs with exotica contained many goods, and vice versa. Contrasts between graves became less sharp. Toumba Tomb 78 (SPG II-III), a shaft grave $1.70 \mathrm{~m}$ deep, had four pots, seven gold attachments, two gold bands and the neck of a bronze vase that was probably imported..$^{42}$ Toumba Tomb 32 had no pots, six bronze fibulae, a smaller quantity of gold and two amber bulbs on two gilt pins, suggesting lack of access to gold. In this comparatively less wealthy grave, though, an imported faience pendant was present. ${ }^{43}$ In LG, only two graves have been found, a cremation and an inhumation, and the correlation between imports and wealth once again breaks down. Cremation is a more expensive way to dispose of the body, but the imported seal was found with the inhumation. ${ }^{44}$

In sum, from LPG through SPG II and then again in LG, any relationship between eastern exotica and elite graves was not a simple equation. Exotica appear in graves that, in their context, seem relatively poorer than others, while there are many graves teeming with goods and built with considerable manpower that have no eastern imports. A variety of objects were deposited in a variety of groupings, and just as there was no single way to inter the dead, so also there was no standardised burial vocabulary, no single function of the exotic as a uniform and consistent status marker, and no rationing of exotica to one cemetery. The absence of clear deposition and distribution patterns contrasts with traditional ranked societies such as the Hallstatt.

\footnotetext{
36 Popham, Sackett and Themelis (1979-80) г69-70.

37 Popham, Sackett and Themelis (I979-80) 257-8.

$3^{8}$ Popham, Sackett and Themelis (I979-80) I48-9.

39 Popham and Lemos (I996) Table I and Plate 59.

40 Popham, Sackett and Themelis (I979-80) I80-I.

4I Popham, Sackett and Themelis (I979-80) I2I, 220.

42 Popham and Lemos (I996) Table I and Plate 74.

43 Popham, Sackett and Themelis (1979-80) I86-8.

44 AR 52 (2005-6) 63; Lemos (2007) I26, I33, Fig. 8.
} 

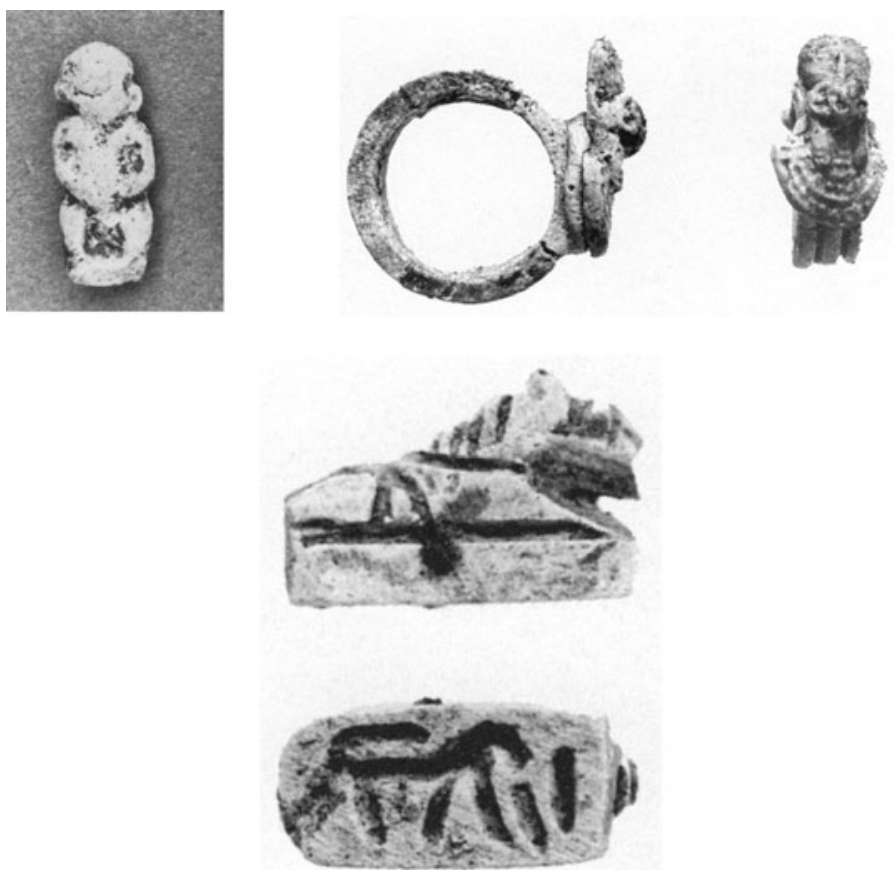

Figure I. Trinkets from Lefkandi: Pataikos (Toumba Tomb 32, 17), an Amen ring (Toumba Tomb 39, 37) and a recumbent lion (Toumba Tomb 38, 55). Photos: John Blazejewski/ Princeton University, after Popham, Sackett and Themelis I979-8o, Plate 235a; Popham and Lemos I996, Plate I42a, g. Reproduced with permission of the British School at Athens. See Table 2 for further information.

The point is not that the elite did not have access to eastern imports, but that there was no straightforward signifying system wherein imports denoted elite, a system into which trinkets could be inserted. So what made these small objects desirable and what type of consumption do they represent? Recognising the limitations of explanations focused exclusively on elite agency opens the possibility that more factors governed the deposition of these objects than socio-political concerns. With this background, we can look more closely at the trinkets themselves.

\section{The mortuary functions of a trinket}

There are sixteen scarabs, scaraboids, seals, pendants or rings from eleven tombs at Lefkandi, from LPG through LG (see Fig. I and Table 2). ${ }^{45}$ Their chronological

45 The table does not include the Bronze Age seals found in Toumba Tombs I2B and 79. 
Table 2: Scarabs, scaraboids, seals, figural pendants and inscribed rings from the Toumba cemetery at Lefkandi.

\begin{tabular}{|c|c|c|c|c|c|c|c|}
\hline Object & Material & Subject matter of intaglio & $\begin{array}{c}\text { Tomb, inventory } \\
\text { number }\end{array}$ & Period & Age & $\begin{array}{c}\text { Basis of age } \\
\text { determination }\end{array}$ & Findspot \\
\hline $\begin{array}{l}\text { ring with Amen } \\
\text { protome }\end{array}$ & faience & & Toumba Tomb 39, 37 & LPG & child & tooth & $\begin{array}{l}\text { near gold pendants } \\
\text { and sword, } \\
\text { possibly at } \\
\text { deceased's left }\end{array}$ \\
\hline $\begin{array}{l}\text { recumbent lioness } \\
\text { (?) pendant }\end{array}$ & faience & & Toumba Tomb 39, $3^{8}$ & LPG & child & tooth & not on plan \\
\hline $\begin{array}{l}\text { ring with Amen } \\
\text { protome }\end{array}$ & faience & & Toumba Tomb 59, 35 & LPG-SPG I & adult & $\begin{array}{l}\text { layout of grave } \\
\text { goods }\end{array}$ & $\begin{array}{l}\text { near two other } \\
\text { rings, at left of } \\
\text { body }\end{array}$ \\
\hline $\begin{array}{l}\text { scarab with lost } \\
\text { bezel }\end{array}$ & faience & & Toumba Tomb 59, 36 & LPG-SPG I & adult & $\begin{array}{l}\text { layout of grave } \\
\text { goods }\end{array}$ & $\begin{array}{l}\text { in faience bowl } \\
\text { along with other } \\
\text { objects including } \\
\text { beads }\end{array}$ \\
\hline $\begin{array}{l}\text { Isis nursing Horus } \\
\text { pendant }\end{array}$ & faience & & Toumba Tomb 22, 28 & SPG I & child & $\begin{array}{l}\text { layout of grave } \\
\text { goods and } \\
\text { feeder }\end{array}$ & $\begin{array}{l}\text { near finger rings } \\
\text { and bracelets }\end{array}$ \\
\hline $\begin{array}{r}\text { Sekhmet(?) } \\
\text { pendant }\end{array}$ & faience & & Toumba Tomb 45, 34 & SPG I & child & $\begin{array}{l}\text { layout of grave } \\
\text { goods }\end{array}$ & $\begin{array}{l}\text { at centre of beads at } \\
\text { south end of } \\
\text { tomb, near } \\
\text { fibulae and } \\
\text { earrings }\end{array}$ \\
\hline
\end{tabular}


Table 2. Continued

\begin{tabular}{|c|c|c|c|c|c|c|c|}
\hline Object & Material & Subject matter of intaglio & $\begin{array}{c}\text { Tomb, inventory } \\
\text { number }\end{array}$ & Period & Age & $\begin{array}{l}\text { Basis of age } \\
\text { determination }\end{array}$ & Findspot \\
\hline recumbent lion & steatite & $\begin{array}{l}\text { garbled 'Menkheperre' or } \\
\text { 'beloved of Amen' }\end{array}$ & Toumba Tomb 27, 15 & SPG I-II & child & $\begin{array}{l}\text { layout of grave } \\
\text { goods }\end{array}$ & not on plan \\
\hline $\begin{array}{l}\text { Ptah-Sokar-Osiris } \\
\text { = Phoenician } \\
\text { Pataikos }\end{array}$ & faience & & Toumba Tomb 32, I7 & SPG II-IIIa & child(?) & $\begin{array}{l}\text { layout of grave } \\
\text { goods }\end{array}$ & $\begin{array}{l}\text { at west end of a } \\
\text { west-east body }\end{array}$ \\
\hline $\begin{array}{l}\text { cuboid amulet in } \\
\text { shape of a } \\
\text { shrine }\end{array}$ & steatite & $\begin{array}{l}\text { two human figures; two } \\
\text { recumbent lions; lion and } \\
\text { mn, 'enduring'; sphinx, } \\
\text { wedjat eye, sun disk; khpr } \\
\text { and } m n \text { 'beloved' }\end{array}$ & Toumba Tomb 36, 2I & SPG II-IIIa & child & teeth & $\begin{array}{l}\text { near beads, } \\
\text { pendants and } \\
\text { diadem }\end{array}$ \\
\hline $\begin{array}{l}\text { ring with } \\
\text { hieroglyphs }\end{array}$ & faience & unpublished hieroglyphs & Toumba Tomb 8o, $6_{3}$ & SPG II-IIIa & adult & $\begin{array}{l}\text { tomb size and } \\
\text { layout of grave } \\
\text { goods }\end{array}$ & not on plan \\
\hline $\begin{array}{l}\text { recumbent lion } \\
\text { seal }\end{array}$ & unknown & not reported & not reported & LG & child & excavation report & not reported \\
\hline
\end{tabular}


distribution is relatively consistent. All are imports from the east and might be classified as 'Aegyptiaka', though it is unlikely that they are specifically Egyptian. These disparate objects may be studied as a group on the basis of their size, portability, foreign origins and inscribed or figured character, and are here classified as trinkets.

A brief survey of figured eastern exotica from the Middle Geometric period and earlier reveals how rare these objects were in their Aegean context. At Athens, two ivory stamp seals, probably carved locally, appeared in an EG II burial, ${ }^{46}$ and a figurine of HatMehit was found in an MG II grave. ${ }^{47}$ At Anavysos, a scarab was placed in an MG II inhumation, ${ }^{48}$ and at Eleusis the so-called Isis burial produced an Isis figurine and three scarabs along with MG pottery and finds, and another scarab accompanied a second burial that dates shortly thereafter. ${ }^{49}$ A figurine of a seated deity was placed in an MG tomb at the Serraglio cemetery on Kos. ${ }^{50}$ Rhodes, probably home to Phoenicians and/or Cypriots, produced more substantial quantities of imports, but mostly from the later eighth century. ${ }^{5 \mathrm{I}}$ An exception is at Ialysos, where a PG burial contained a bone amulet with stamped circles, a faience figurine of Bes and a faience pyramid seal..$^{2}$ There are more finds on Crete, particularly from the Knossos area. At Vrokrastro, two tombs with late tenth- or early ninth-century burials contained a total of seven seals. ${ }^{53}$ At Knossos, Fortetsa Tomb 6 dating to EPG contained a faience ring with a schematic royal cartouche, ${ }^{54}$ and Fortetsa Tomb 9 dating to the PG period contained a faience amulet of Sekhmet. ${ }^{55}$ There were two scarabs deposited in the late ninth-century Tekke 'Jeweller's' tomb $b^{56}$ and one in an MG burial on the lower Gypsades. ${ }^{57}$ Eleftherna has produced a faience figurine of Sekhmet with a possible Phoenician or Aramaic inscription in an MG-LG burial pithos..$^{8}$ The more plentiful finds on Cyprus will be discussed below.

Only in the LG period did minor, figural imports appear in abundance throughout the Aegean, increasingly in sanctuaries rather than graves. Aegyptiaka were made at Rhodes, and in the seventh century Naukratis began to provide a steady supply. ${ }^{59}$ In Italy,

\footnotetext{
46 Smithson (ig68) II5-I6, nos. 79-80.

47 Skon-Jedele (I994) 59-62, no. 2.

48 Skon-Jedele (I994) 77, no. 22.

49 Pendlebury (I930) 8o, nos. I6o-4; Skon-Jedele (I994) II8-I9, I2I, I28, nos. 24, 25, 28, 29, 39.

50 Skon-Jedele (I994) I967-8, no. 2990.

5 I Kourou (2003).

52 Lemos (2002) 226; Coldstream (2003) 46-7.

53 Pendlebury (I930) 39, nos. 58-64; Skon-Jedele (I994) I944-5, nos. 2970-6; Hoffman (I997) 86-7, nos. I24-30.

54 Skon-Jedele (I994) I866, no. 29I4; Hoffman (I997) 39, no. 24.

55 Skon-Jedele (I994) I859-6o, no. 2899; Hoffman (I997) 39, no. 25; Karetsou (2000) II.356, no. 389b.

56 Skon-Jedele (I994) I863-5, nos. 2906, 2909; Hoffman (I997) 87-8, nos. I32-3, I9I-245; Kotsonas (2006).

57 Skon-Jedele (1994) I864, no. 2907; Hoffman (I997) 88, no. I34.

58 Stampolidis (I998) I78, Fig. 6; Karetsou (2000) II.359, no. 394; Stampolidis (2004) 294, no. 395.

59 Gorton (I996) ז64-80.
} 
Egyptian(ising) scarabs appeared in the first half of the eighth century, at Veii, Tarquinia, Cumae, and especially Capua and Pontecagnano, possibly carried by Greeks. ${ }^{60}$

In its geographical and chronological context, therefore, the quantity of minor exotica at Lefkandi stands out, even if the overall number at first appears to be small. They were among the most manifestly exotic objects at the site, bearing foreign imagery, inscribed with foreign symbols (hieroglyphs), and even representing foreign deities. With their outlandish visual idioms, they appeared more exotic than a bronze pitcher or gold bands. Iconography, signs and/or raw materials were dramatically 'other', neither local nor locally imitated. But, as discussed, small and worn close to the body, they were not prestige-goods on par with, for instance, a bronze bowl. They may have had a strong visual interest, but their semantic message was not directed towards an audience of observers such as a group of mourners; they were not for display. Who would want to showcase such cheap material? Steatite was neither rare nor hard to work, and faience was friable. Admittedly, it is difficult to recover ancient perceptions of materials, and in the Bronze Age faience production may have been centrally controlled and used primarily in religious contexts, valued for its lustre and composite character, but by the Late Bronze Age faience was not uncommon. ${ }^{61}$ And while the scarcity of faience objects in the Early Iron Age Aegean might suggest that it had high value, Georg Nightingale has shown that the faience at Lefkandi was of low quality. ${ }^{62}$ Most significantly, many of the faience objects found at the site were made in moulds, and thus bore the visible traces of mass production. Some of the trinkets at Lefkandi even occur in exact duplicates. One can infer that consumers at Lefkandi were aware that the objects were not unique but serially produced. The act of placing a scarab in a gold setting (Toumba Tomb 36, 20) to increase its worth exposes the intrinsic low value of these trinkets.

Trinkets were notably absent from the most prestigious burials at Lefkandi: the cremation and inhumation within the apsidal building. In addition, Crielaard has convincingly identified ten Cypriot elite tombs with certain defining characteristics, many of which were shared with the Lefkandi building burial: the dead were the first to be interred in a new cemetery; they received cremation, particularly in urns; they were accompanied by weapons and dining equipment; and frequently they also were accompanied by antiques. ${ }^{6}$ In only three of these elite tombs was the deceased buried with a trinket, although such objects were not uncommon on Cyprus. ${ }^{64}$

In the decades after grave deposits end at Lefkandi, these minor objects were certainly not restricted to a Greek elite, as evidenced by the distribution of scarabs and scaraboids.

6 Hölbl (1979) I.I44, I46, I52, I55, I57.

6I Sherratt (2008). Brisart (20II) maintains that faience amulets and statuettes, even when appearing in large numbers in the Archaic period, could still be prestige items (pp. I05-6). Further on faience: Webb (I978); Hoffman (I997) 136-9; Caubet and Pierrat-Bonnefois (2005).

62 Nightingale (2007).

63 Crielaard (I998). Similarly Catling (I997).

64 Salamis Tr; Palaepaphos-Skales T89; Amathus T523. 
Beginning in the eighth century, they were deposited in sanctuaries in too great a quantity by hundreds and sometimes thousands - to be the purview of one narrow social group. At Pithekoussai, scarabs, scaraboids, lyre-player seals, cartouche rings and eastern figurines were deposited in tombs that have been rightly characterised by the excavator as non-elite (in contrast with princely burials at Cumae and Eretria) because of the grave assemblages and the large number of tombs. ${ }^{65}$ Günther Hölbl explains away the quantity of Aegyptiaka at Pithekoussai as an exception to elite Italian consumption due to the ostensibly low price of scarabs at such a trading centre, ${ }^{66}$ but it is more likely that these minor objects were already generally inexpensive in the Early Iron Age.

So it seems that a small number of people at Lefkandi decided to deposit trinkets, for reasons unrelated to socio-political display. A closer look at the mortuary deposition of scarabs, scaraboids, seals and figured/inscribed pendants and rings demonstrates that these minor objects performed a particular function in their context. Data on age is difficult to obtain for Lefkandi, because most of the organic remains have not left a trace, yet close analysis of the published, scaled plans and the grave goods indicates a correlation of trinkets with age (see Table 2). Two burials with bones that were present and analysed show that children were interred (Toumba Tombs 36 and 39). ${ }^{67}$ For other graves, it is possible to determine whether the deceased was an adult or a child on the basis of the size of the grave, the type of grave offering and/or the layout of the offerings. That is, vessels were laid around a corpse wrapped in a burial shroud pinned with fibulae, and jewellery and other personal adornments were placed on the body or shroud. It is thus possible, for instance, to calculate that the deceased in Toumba Tomb 46 was less than half a metre tall; in Toumba Tomb 22, just over a metre (and note that a feeder was also present); in Toumba Tombs 45 and 27, well less than a meter; and in Toumba Tomb 38, about a metre. ${ }^{68}$ The deceased in Toumba Tomb 32 was not surrounded by enough offerings to take a straightforward measurement. S/he could have been as tall as $\mathrm{I} .4 \mathrm{~m}$, but grave goods laid on the body (the only goods in the tomb) cover only about $0.80 \mathrm{~m}$ of the tomb length. Table 2 makes clear what criteria have been used to establish if the deceased was an adult or a child.

Not only were the minor, inexpensive, portable imports deposited with children, but there was a close relationship between the objects and the bodies of the deceased. The objects were pierced to be worn around the neck, and rings obviously were made for the fingers. The placement of the grave goods within the tombs indicates that trinkets were deposited near the head or chest of the deceased, as shown by their location at one end

65 Boardman and Buchner (I966); de Salvia (1978), (1993); Hölbl (1979) II.I77-96, nos. 740-856; Ridgway (1992) 65-7, 77; Skon-Jedele (1994) 1257-1340.

66 Hölbl (I979) I.239 n. 5I. Hölbl (1987) believes that the popular use of Aegyptiaka began only in the eighth century.

67 Excavators have suggested that Toumba Tomb 39 was a double burial: Lemos and Mitchell (2011) 636. Coldstream ((1998) 356 and (2007) 137-8) believes it included a woman, and that the quantity of faience in the grave indicates she was a Near Eastern bride.

68 Lemos and Mitchell (20II) argue that Toumba Tomb 38 belonged to a high-status woman because of the gold pendant in the grave (pp. 637-8). 
of the grave (Toumba Tomb 32) and proximity to earrings (Toumba Tomb 45) or diadem (Toumba Tomb 36). ${ }^{6}$ Sometimes the trinkets were found with necklace beads that may have been on the same string (Toumba Tomb 46). The pendants in Toumba Tomb 22 may have been laid next to the deceased, and the grave goods in Toumba Tomb 38 seem slightly scattered and disturbed, but otherwise there is a close connection between object and corpse. The adult burials differ significantly: in Toumba Tomb 59, the scarab was placed in a faience jar, and in Toumba Tomb 79, a burial for a warrior-trader, the cylinder seal was outside the funerary cauldron.

Although some of the trinkets recall seals, which in many regions and periods were closely associated with their owners and worn on bodies, it is clear that at Lefkandi these objects were not generally used for sealing, for sealings were preserved in Toumba Tomb 22, but without any figural seal impressions. The North Syrian cylinder seal in adult Toumba Tomb 79, found along with a scale and weights, may be an exception. ${ }^{70}$ In contrast, the children buried with seal-like objects would have had no need to engage in sealing activity. They held no political power and were not yet fully socialised beings.

The significance of these manifestly foreign objects can be deduced from formal properties, placement close to the corpses of children, and contemporary parallels. The inscribed hieroglyphs bore formulas apposite for burial contexts, the figured deities were associated with fertility and/or averting evil, and scarabs were linked with concepts of regeneration and renewal. Families used these objects to invoke foreign deities or forces, so as to capture their power or to protect against them in a mortuary context. They are best understood as amulets or talismans. Amuletic practice was common in Egypt and quickly spread to the Near East and thence to Cyprus. ${ }^{7 x}$ The garbled hieroglyphs, the style of the Lefkandi trinkets and the absence of distinctly Egyptian funerary amulets like heart scarabs make a Near Eastern or Cypriot rather than Egyptian origin most likely. The deposition of the trinkets foreshadows practices at Pithekoussai, where such objects were buried overwhelmingly with children and/or sub-adults, and were placed near the chest and neck. ${ }^{72}$

In a study of perceptions of Phoenician traders, Susan Sherratt suggested that over time some Lefkandi residents thought that they had been 'fobbed off' by faience wares that would be regarded 'as not much more than the equivalent of children's toys in their place of origin'. ${ }^{73}$ This statement, while acknowledging the low material value of trinkets, neglects

69 Excavators thought the head was at the other end of the grave because a hair spiral was found there: Popham, Sackett and Themelis (1979-80) 187.

70 Kroll (2008) 43-4.

$7 \mathrm{I}$

Generally on amulets: Vercoutter (1945) 264-8; Hölbl (1979) I.104-6; Faraone (I99I); Andrews (1994). Using an Egyptian lens to study exotica in mainland Greece - as do de Salvia (I978); Hölbl (I983), (1987); Skon-Jedele (1994) - has left the Near Eastern amulet parallels out of the picture. Production in the Levant: Keel (1995) 2939; Nunn (2004). Association of scarabs with children at Late Bronze Tell el-Far'ah (south): Braunstein (201I).

72 Amulets at Pithekoussai: de Salvia (1978).

73 Sherratt (2010) I3I. She argues that over time, materials such as rock crystal and amber with widely acknowledged value were increasingly deposited as residents at Lefkandi recognised the low value of faience (esp. pp. I3O-I). Her 
their prevalent use in tombs in the Near East. Such widespread consumption was driven by the belief or at least the hope that talismans might work. The Phoenician cemetery (tenthseventh centuries) of Tyre Al-Bass provides a recently published parallel for the practice. Here non-elite were cremated and placed in one or two urns, with scarabs in 20 per cent of the burials, mixed with the bones or placed at the top of the urn. ${ }^{74}$ The cemetery at Azor provides another recently published Levantine example. ${ }^{75}$ Mourners who placed trinkets in the graves at Lefkandi similarly believed they would protect the dead on an eschatological journey, or protect the living from the restless spirit of the dead. Without literary sources, it is impossible to be more precise. Children seem to have been selected for this treatment because they were not yet fully developed social and physical beings, and thus were particularly in need of help on a journey or of propitiation. Elsewhere in the Early Iron Age, including among members of Lefkandi's cultural koine, the bodies of children also received different sepulchral treatment from adults. They were not accompanied by trinkets, but were frequently interred rather than cremated, and placed in intramural graves. ${ }^{76}$

Although we cannot be very precise about the details of beliefs, the deposition of trinkets with children at Lefkandi represents an amuletic or talismanic practice negotiating the relationship between mourners and the body as well as the spirit of the deceased. There are, of course, social dimensions to this practice: special treatment of children indicates that lineage was important to the society, and the ability to provide a particularly powerful protection for or against the dead may have been considered a privilege. Talismanic practice, however, also introduces an important and underemphasised explanation to the consumption at Lefkandi and the variation therein, which cannot be subsumed under socio-political readings: varying conceptions of the power of the exotic.

Recovering the talismanic function of some of the objects in the tombs offers an addendum to interpretations of eastern exotica as elite consumption, reflections of social status or vestiges of economic models dominated by an aristocracy. Although work on mortuary variability has succeeded in exposing the rich complexity of funerary rituals and the difficulty in moving from archaeological remains to descriptions, explanations and analyses of the many actions, objects and motivations entangled in the rites for the dead, ${ }^{77}$ comparatively little scholarship has attempted to assess beliefs, conceptions or superstitions about the dead and the afterlife. ${ }^{78}$ Few archaeologists have denied the role of belief in funeral ritual, but many today doubt its role as a primary cause of variability,

statistics are misleading because each faience bead in a large faience necklace is calculated as one faience object (p. 127, Table 6.I).

74 Aubet (2004) 59, (2010); Gamer-Wallert (2004). On the status of tombs: Aubet (2004) 6r. See also the discussion of exotica at Lachish in Heymans and van Wijngaarden (201I) $132-3$.

75 Mazar (2004); Ben-Shlomo (2008).

76 Child burials: Mazarakis Ainian (2007-8), (2010), (2012) 84. Survey of PG burial practices: Lemos (2002) I5I-86.

77 E.g. Ucko (1969).

78 Notable exceptions include Carr (1995). Anthropologists have been less hesitant to consider eschatology: Metcalf and Huntington (1991) 79-107. 
and hesitate to use material evidence to recover eschatology in a prehistoric period. ${ }^{79}$ But variation in belief begins to explain why some people at Lefkandi deposited trinkets while others did not, and opens the possibility that other goods, too, were placed in graves because they had a particular eschatological function. Differences in fashion, taste, belief or cognitive frameworks, in addition to economic well-being, explain the heterogeneity within the grave assemblages at Lefkandi as well as its regional exceptionalism.

This amuletic practice itself, however, needs further explication. As Lewis Binford maintained, 'The argument against an idealist position is, of course, to point out that, by a referral of observed differences within one class of phenomena (behavior) to postulated differences within another (ideas), we are forced to seek the explanations for differences in ideas and in the conditions favoring their change. ${ }^{80}$ The rest of this article will, accordingly, consider three interrelated causes or conditions for the talismanic value of minor exotica at Lefkandi: continuity with the past, foreign influence and the monumentalisation of eschatology.

\section{Three conditions of talismanic practice at Lefkandi}

There were precedents for burial with amulets. In LH IIIC, not only adults but especially children received intramural burial at Lefkandi, interred underneath floors and close to walls. One burial was accompanied by a 'vaguely humanoid' green steatite stone amulet, with incised circles on one flat side. ${ }^{8 \mathrm{I}}$ Perhaps people discovered such burials at Lefkandi with amulets when repurposing the site in the Early Iron Age. Amulets, including lowvalue trinkets, were more common at LH IIIC Perati in Attica, where there were more imports than anywhere else on the mainland at this time: thirty-five scarabs, figurines, seals, rings and crescent or rosette ornaments from fourteen tombs, with one surface find. ${ }^{82}$ Elsewhere, glass and soft stone seals were deposited in Late Helladic tombs in Phthiotis and southern Thessaly. In particular, at Elateia, simple steatite, pressed glass and fluorite sealstones were deposited in large numbers in post-palatial and PG graves, and some of them were made exclusively for the tomb. ${ }^{83}$ Perhaps the practice at Lefkandi was acquired through contact with such places on the mainland, where seals continued to be deposited with the dead. The pottery record, at least, attests to some form of contact among Euboea, Attica and Thessaly in the Early Iron Age.

79 Binford (I97I) 25: 'differences in ideas and knowledge, while possibly relevant as prerequisites to change and differentiations, are never sufficient causes for such changes and differentiations'. Cf. Fogelin (2007), surveying archaeological views on the relationship between religion and ritual.

80 Binford (1971) 7 .

8I Evely (2006) 58, 28I, Fig. 5.8, Plate 83.4.

82 Iakovidis (1980) 83-9.

83 Dakoronia, Deger-Jalkotzy and Sakellariou (1996); Dickers (200I) 9, 77-8, 90-2, I09-17; Krzyszkowska (2005) 2705. On the deposition of low-value exotica in non-elite Mycenaean tombs see also Heymans and van Wijngaarden (20II) I27-9. 
The chronological gap between much of this activity together with the limited use of amulets at Lefkandi, however, suggests an external stimulus was also necessary. The eastern character of the Lefkandi trinkets indicates that the stimulus came from overseas, and the particular use of the objects implies that people and not just goods were on the move. The trinkets, that is, were not sold with instructions. The deposition of these objects was imagined to be a powerful and efficacious act, and such a practice was not commercially acquired along with an object but learned at a more personal level. So it is most likely that residents of Lefkandi travelled to a place where they observed or heard about the power of amulets, or that people migrated to Lefkandi and brought the practice with them. The two options are not, of course, mutually exclusive. ${ }^{84}$ Euboeans probably were themselves involved in trade, commerce and military ventures in the east by the LPG period, when Euboean vessels (among them amphorae) appear at Tyre and Cyprus. There are also signs of immigrants and intermarriage at Lefkandi. Athenian trench-and-hole burials stand out in the Toumba mortuary record. ${ }^{85} \mathrm{~A}$ cauldron burial of a warrior-trader (Toumba Tomb 79) containing Phoenician and Cypriot jugs, a scale, weights and a cylinder seal has an excellent parallel at Achziv. ${ }^{86}$ The skilled working of metals, an MG cup with a Semitic inscription from Eretria and the historical tradition that Phoenicians were on the island all build the case for the movement not just of goods but also of people - people who valued trinkets and knew how to use them. ${ }^{87}$ Similarly, at Pithekoussai, where trinkets were deposited in considerable number, there is good evidence for foreigners. ${ }^{88}$

The lack of eastern parallels for the majority of Lefkandi burials does not militate against the presence of immigrants, for burial forms in Phoenicia varied significantly. Moreover, burials are not always a clear sign of ethnicity. The tombs of Euboean colonists at Pithekoussai, for instance, were not especially Euboean in form, and on Cyprus, despite the attested mix of Greeks, Eteocypriots and Phoenicians, burial forms quickly assumed a rather uniform appearance (dromos and chamber tomb). ${ }^{89}$ Although many scholars have been sceptical about identifying migration in the Early Iron Age archaeological record,,$^{90}$

84 Foreigners at Lefkandi: Papadopoulos (1997) 206; Coldstream (1998) 356, (2007) (only admitting some); Fletcher (2006) 19r. See also Fletcher (2011) 13-17.

85 Trench-and-hole burials: Toumba Tombs I8, 50, 58, and see also Toumba Tombs I4.I, I4.2 and 55; Lemos (2002) 163-4. Lemos (2003) ignores the Athenian-style burials in her criticism of immigrant burials at Lefkandi.

86 The origins of the deceased in Toumba Tomb 79 have been debated. Immigrant: Antonaccio (2002) 29; Papadopoulos (1997) 192. Euboean: Popham and Lemos (1995); Kroll (2008). Parallel to tomb at Achziv: Nijboer (2008).

87 Jewellery: Popham, Sackett and Themelis (1979-80) 218-22. Foundry remains: Popham, Sackett and Themelis (1979-80) 93-7. Cup: Kenzelmann Pfyffer, Theurillat and Verdan (2005) 76-7, no. 66. Literary sources: S. P. Morris (1992) I40. Sceptical: Coldstream (2007).

88 Ridgway (I992) III-I8.

89 Phoenician burials: Sader (1995), (2014-15); Dixon (2013); Aubet-Semmler and Carreño (2014-15). Variety and adaptability of Phoenician burials: Gras, Rouillard and Teixidor (I99I) 139-4I. Heterogeneity of Cypriot burials and difficulty in finding traces of ethnicity: Janes (2010).

90 E.g. Hoffman (1997), (2005). 
the discoveries of a Phoenician shrine at Kommos and of cippi at Knossos and Eleftherna, although admittedly later in date, make such doubts increasingly tenuous. ${ }^{\text {I }}$

Any easterners active in the Early Iron Age Aegean are usually identified as Phoenicians, but there is evidence that connections between Cyprus and Lefkandi were relatively strong, and it is probable that the practice of depositing amulets was imported by Cypriots or learned by residents of Lefkandi travelling to Cyprus..$^{22}$ The close relationship in material culture between Cyprus and Phoenicia renders distinguishing the two difficult, ${ }^{93}$ but many finds at Lefkandi can be attributed more closely to Cyprus than Phoenicia, beginning in the earliest Iron Age tombs. A Cypriot bird vase was buried in a Lefkandi EPG grave along with a local imitation. ${ }^{94}$ EPG local pottery at Lefkandi, such as the straight-sided pyxis, the bird vase and the lentoid flask, ${ }^{95}$ demonstrates the impact of Cypriot models and/or resident Cypriots either producing the goods or creating a demand. The remains of the man in the apsidal building were buried in a Cypriot antique, possibly a family heirloom, ${ }^{96}$ and imported objects from Cyprus abound following the construction of the apsidal building: flasks, mace, white-painted and blackon-red jugs, a wheeled stand, and possibly some of the bronze vessels. The gold diadems at Lefkandi also have good parallels on Cyprus. ${ }^{97}$ Euboean pottery appeared in Cyprus in the Protogeometric period, particularly along the southern coast, and was imitated at Amathus. ${ }^{98}$ Most importantly, on Cyprus, amulets - both local sealstones and imported Aegyptiaka, of low- and high-value material - occur in the earliest levels of Iron Age burials. ${ }^{99}$ Amathus, with its combination of early Greek and Phoenician imports, may be

9I Kommos: Shaw and Shaw (200o). Cippi: Stampolidis (2003) 22I-4, (2004) 238, no. 257. See also Morris and Papadopoulos (1998) esp. 26r-2.

92 On early relations between Cyprus and the Aegean, stressing the important role of Cyprus: Crielaard (I998); Kourou (2008a), (2008b) 357, (2012). Cyprus as intermediary: Popham, Touloupa and Sackett (1982) 247.

93 Cypro-Phoenician interaction: Gilboa, Sharon and Boaretto (2008); Smith (2008).

94 Popham, Sackett and Themelis (I979-80) II4-I5.

95 Popham, Sackett and Themelis (1979-80) 285.

96 On the 'inhabitants' of the apsidal building, most recently: Mazarakis Ainian (2012) $77^{-8}$.

97 Popham, Sackett, and Themelis (1979-80) 219; Karageorghis (1998).

98 Coldstream (1986).

99 Heymans and van Wijngaarden (20II) discuss exotica on Cyprus (p. 132). Some of the first amulets appear in the eleventh-century Tomb I at Salamis: a faience scarab partly covered in gold, a limestone conical seal with a roughly carved quadruped and man, and a fragmentary faience figurine (Yon (I97I) I4-I6, 20, 2I, nos. 29, 40, 44). At Palaepaphos, a large grey schist scarab and faience pyramidal stamp seal were found in a tomb used in CG IA (Karageorghis (1983) 312-26, T89:17, T89:55). One faience scarab was found in a tomb used during CG IB-II (Karageorghis [1983] 269-78, T82:17), and three were found in a CG III tomb (Karageorghis (1983) 302-9, T86:2, 5, II). A faience ring was associated with two mid-CG III to early CA I burials (Karageorghis (I983) I94202, T74:40). Also at Palaepaphos, old seals were reused as amulets: a Bronze Age cylinder seal was located in a CG III burial along with another antique cylinder seal that had been recut (Porada (1983) 407-9, T71:Ia and T71:46), and two Bronze Age domed stamp seals were also reused in CG I-II tombs (Karageorghis (I983) IIII2, I58-76, T57:I, T67:I15). At Amathus, CG II and CG III burials contained scarabs and amulets, accompanied in the first case by Phoenician pottery (Clerc (I99I) 39-40, T312/6o, T312/65; 8-9, Ti42/77, T 142.IIo; on dates: Clerc (I99I) 50). At Kaloriziki, a faience dome-shaped pendant appeared in a CG IA funeral context (Benson (I973) 43-5, I27-8, KII65), while an incised terracotta pendant was found with a CG IA child's burial (Benson 
the best candidate for a multicultural setting for learning amuletic practices, or for Cypriot immigration to Lefkandi.

Traditional beliefs strengthened or (re)stimulated by foreign influences are still not sufficient to explain the talismanic practice at Lefkandi. Why do imports not appear in such numbers at other sites where the historical record or excavation suggests close contacts with Cyprus and the east? The third necessary condition is the topography and phenomenology of the Toumba cemetery. Unlike the other necropoleis at Lefkandi, and unlike the cemeteries elsewhere in the Aegean, the graves at Toumba were laid out at one end of an enormous, elaborate apsidal building covered by a low tumulus. Much of the discussion of this monument has focused on the chronology of events, namely, whether it was initially constructed as a residence or as a funeral building. ${ }^{100}$ The evidence for an intended sepulchral purpose is strong: there are no other residences in the area; the building was incomplete and hardly used; the central colonnade was widened around the burials, indicating forethought; and the cremation fire from the burial pit predates the floor above it. ${ }^{\text {Ior }}$ Nevertheless, in focusing on such sequences of events, it is possible to miss the forest for the trees. Regardless of why it was first built, the monument was the largest structure in the area and the focal point of the graves; it had a profound visual impact. And whether it was intended as a home or a tomb, ultimately it was a house cum tomb, a monument that gave visual form to ideas about memorialising the dead and about the importance, potency and afterlife of the dead. Built, doubtless, as an extravagant burial marker elevating the social status of the deceased and their families, it engendered mortuary ideas and practices, which would have been reinforced over the years as more and more people laid graves around the tumulus. As a sepulchral house, the monument fostered the notion that the dead should be cared for and that, in some way, they resided in the tomb. The fact that Toumba Tomb 68 echoes the burials in the apsidal structure suggests that there was a collective memory of what lay under the mound. ${ }^{\mathrm{IO} 2}$ Moreover, the placement of tombs specifically around the eastern edge of the mound, where the entrance to the apsidal building had been located, and sometimes cut into the mound itself, further suggests that people remembered the covered building's structure and that they desired to make a meaningful connection to the building and to the residents within.

(1973) 28-9, I27, Ki158). From Kition's votive deposits, only one Ptah figurine and one scarab can be associated with a secure pre-8oo context (Clerc, Karageorghis, Lagarce and Leclant (I976) II, III-I2, I62-3, nos. 336I, 3365, from Bothros 16). Smith (2009) argues that the Bothros postdates the use of Floor 3, which she dates to c. 850-707 (p. 2II).

Ioo Residence: Calligas (I988) 232; Whitley (I991a) 185-6; Crielaard and Driessen (I994); Mazarakis Ainian (1997) 4858. Building post-burial: Popham, Calligas and Themelis (1993); Antonaccio (2002) I8-22; Lemos (2002) I40-6, 166-8. Mazarakis Ainian seems to be revising his earlier viewpoint that it was originally a domestic structure: Mazarakis Ainian (2012) 76.

Ior Popham, Calligas and Themelis (1993) 49-52, 97-гог.

I02 Popham and Lemos (1996) Plates 21, 22, 35a-b. 
It is possible that the monument was conceived as a heroön, for there are some features within the apsidal building that may have been used for ritual purposes. Moreover, a krater near the burials may have received libations, and in front of the tumulus an area at least $7.5^{\times}$ $3.0 \mathrm{~m}$ was flattened out and a large tripod erected, perhaps serving as a place for feasting or other ritual activity. ${ }^{\text {I03 }}$ No offerings, however, have been identified, and the designation heroön is probably anachronistic and narrow. Nevertheless, the structure monumentalised the practice of honouring, protecting and remembering the dead, and provided a focal point for conceiving of a continued presence of the deceased. Such a mortuary landscape provided suitable grounds for talismanic practice to flourish.

\section{Conclusion}

Nicolas Coldstream, an authority on the Early Iron Age, prefaced a discussion of foreigners at Lefkandi with the following assertions:

We can dispense quite briefly with the supposition that a large quantity of imported orientalia in the richer tombs must necessarily indicate the presence of merchants from the East Mediterranean. No: these eastern exotica take their place in the richer tombs beside fine imports from Athens and elsewhere, and are better explained as displaying the eclectic tastes of a local aristocracy, always interested in eastern and other foreign contacts, but always interred in accordance with the peculiar local burial rites. Some eastern merchants may well have resided at Lefkandi, but we will not find them among the burials so far excavated. ${ }^{\text {I04 }}$

Coldstream does not define 'richer tombs'. Perhaps, as so often in scholarship, the presence of orientalia is used to define a richer tomb and then ... a richer tomb contains orientalia. A close look at the contents of several graves has demonstrated instead that the connection between imports and status is assumed more often than it can be proven. The alleged inhabitants of the tombs, Coldstream's 'local aristocracy', also pose problems, for the consumption pattern and regional exceptionalism at Lefkandi do not fit well into models of prestige-goods or gift-exchange. Coldstream's recourse to 'eclectic tastes' gives up the game. It is the 'eclectic tastes' of the buriers that requires explanation; taste is the question, not the answer. This eclecticism extends to burial types, which we now know were not as uniform as Coldstream implies. ${ }^{\text {IO5 }}$

The two most prevalent reconstructions of the social structure at Lefkandi - a 'Big Man' society or a closed aristocracy - appear increasingly limited in explaining the site. ${ }^{\text {IO6 }}$ The

I03 Krater: Lemos (2002) I67. Tripod: Popham, Sackett and Themelis (I979-80) 2I4. Heroön: I. Morris (2000) 2I8-38. I04 Coldstream (2007) I35. This passage is also discussed in Papadopoulos (20II) II5.

I05 In the same contribution, he freely acknowledges Athenian-style burials: Coldstream (2007) I38-9.

Io6 E.g. Whitley (I99rb) 347; Antonaccio (2002); Muhly (2003) 25-6 (without, however, applying the term 'Big Man').

Aristocracy: Lemos (2002) 218. 
preliminary excavation reports of the settlement indicate that it was not an unstable social system, as once was thought. Settlement at Xeropolis instead was continuous, and the community flourished after the death of the supposed Big Man in the apsidal building, rather than disintegrating, as Big Man models demand. ${ }^{\text {I07 }}$ The lack of spatial delimitation to the Toumba cemetery, the absence of clear symbols of rank and the variety of depositional practice and burial goods speak against seeing it as the resting place for one group. Lefkandi is perhaps best characterised as a multicultural, proto-urban trading community, oriented towards the coast and closely linked with a variety of peoples. ${ }^{\text {Io8 }}$ It was a well-connected node in an expanding network. Although the Toumba cemetery has been interpreted as the burial plot for the richest family in Greece, it is more likely that it was a burial ground for multiple families marked by immigration and marriage across cultural divides and holding varying views on death and burial ritual.

Trinkets were one manifestation of these beliefs. Some grave goods were made specifically for burial, such as some ceramic vessels or gold items too flimsy to be worn, and objects other than trinkets testify to a complex eschatology. The most well-known example is the Lefkandi centaur, a wheel-made figurine deposited in two separate graves: the body was placed on top of the cover slabs of Toumba Tomb 3, with an iron knife or dagger in the grave itself, and the head was laid in Toumba Tomb I. ${ }^{\text {rog }}$ Some of the excavators, astonishingly, argued that the figurine was an object once valued by two family members and broken upon their death so that they both could share it. ${ }^{\text {II }}$ Petros Themelis was surely closer to the truth when he suggested that this action represented the ritual slaying of a death daemon ${ }^{\text {III }}$ - the types of malevolent hybrid beings warded off by a powerful amulet. Speculation can quickly run rampant here, and it is not possible to be very specific about what people thought. But that different people thought different things, and that these thoughts were learned at a personal level, were structured in part by the funerary landscape, and were reflected in the varied grave goods, is hard to dismiss.

I have focused on a group of objects whose form, contexts and comparanda permit a climb up Hawkes's ladder of inference. It is uncertain to what extent high-status items such as metal bowls and cauldrons or gold jewellery shared mortuary meaning with the minor amulets; surely some did. My purpose has not been to explain the function of all the grave goods, but to argue, first, that beliefs and world-views were to some extent operative and in part explain variability, and, second, that some of these beliefs involved either immigration or contact at intimate, personal levels, situations in which practices could be transmitted and ideas about the dead shared. Coldstream himself argued that

\footnotetext{
I07 Sahlins (I963).

I08 Cf. Kramer-Hajos (2009), discussing how emerging LH IIIC communities were oriented towards the coast and marine activity.

Iog Desborough, Nicholls and Popham (I970); Popham, Sackett and Themelis (1979-80) I68-70, 344-5; Lemos (2002) 98-9.

IIo Desborough, Nicholls and Popham (I970) 22. They allow that other explanations are possible.

III Popham, Sackett and Themelis (I979-80) 2I5. Cf. Faraone (I99I) I95-6.
} 
intermarriage was visible at Lefkandi in a tomb with faience vessels, ${ }^{\mathrm{II} 2}$ but I maintain that the cultural connection was more widespread and not restricted to the movement of women alone.

Talismanic consumption was not contingent upon economic factors, but depended on a latent belief stimulated by Cypro-Phoenician customs, on the one hand, and the monumentalisation of eschatology, on the other. Intermarriage, immigration or Euboean travel abroad may explain the encounter with eastern ideas, and large numbers need not have been involved. Talismanic practice cannot explain the consumption of all goods at Toumba, but it suggests that varying eschatological beliefs in addition to varying sociopolitical structure best explain the archaeological record at the site. What is important is that the cultural contact involved more than objects of display - ideas, too, were on the move, and along pathways not restricted to elite mechanisms of exchange. By unlinking intercultural exchange from a narrow elite, it is possible to recover multiple channels through which movement and communication occurred in the Early Iron Age, and to restore agency to actors largely neglected from archaeological literature: children and the sub-elite. If the cemeteries of Lefkandi represent the beginning of a dynamic renewal of contacts between Greece and the east, then perhaps the origins of Orientalising lie not so much in an emergent, decadent elite turning to the luxurious east, but in humble objects and new ideas on the move.

\section{Works Cited}

Ames, K. M. (2008) 'The archaeology of rank', in R. A. Bentley, H. D. G. Maschner, C. Chippindale (eds.), Handbook of archaeological theories, Lanham, MD, 487-513.

Andrews, C. (1994) Amulets of ancient Egypt, London.

Antonaccio, C. M. (2002) 'Warriors, traders, and ancestors: the "heroes" of Lefkandi', in J. M. Højte (ed.), Images of ancestors, Aarhus, 13-42.

Aubet, M. E. (ed.) (2004) The Phoenician cemetery of Tyre Al-Bass: excavations, 1997-1999, Beirut.

(2010) 'The Phoenican cemetery of Tyre', NEA 73, I44-55.

Aubet-Semmler, M. E. and Carreño, L. T. (2014-15) 'Pratiques funéraires à l'Âge du Fer II au Liban: la nécropole de Tyr al-Bass', Archaeology and History in the Lebanon 40-I, II8-34.

Bartel, B. (I982) 'A historical review of ethnological and archaeological analyses of mortuary practices', JAnthArch I, 32-58.

Ben-Shlomo, D. (2008) 'The cemetery of Azor and Early Iron Age burial practices', Levant 40, 29-54.

Benson, J. L. (1973) The necropolis of Kaloriziki, Göteborg.

Binford, L. R. (I97I) 'Mortuary practices: their study and their potential', in J. A. Brown (ed.), Approaches to the social dimensions of mortuary practices (Memoirs of the Society for American Archaeology 25), 6-20.

Boardman, J. (200I) 'Aspects of “colonization”', BASOR 322, 33-42.

Boardman, J. and Buchner, G. (I966) 'Seals from Ischia and the lyre-player group', JdI 8I, I-62.

Braunstein, S. L. (201I) 'The meaning of Egyptian-style objects in the Late Bronze cemeteries of Tell el-Far'ah (South)', BASOR 364, I-36.

II2 Coldstream (1998) argues that faience vessels suggested personal links among the elite of Tyre and Lefkandi, possibly intermarriage. 
Brisart, T. (20II) Un art citoyen: recherches sur l'orientalisation des artisanats en Grèce proto-archaïque, Brussels. Calligas, P. G. (1988) 'Hero-cult in Early Iron Age Greece', in R. Hägg, N. Marinatos and G. C. Nordquist (eds.), Early Greek cult practice, Stockholm, 229-34.

Carr, C. (1995) 'Mortuary practices: their social, philosophical-religious, circumstantial, and physical determinants', Journal of Archaeological Method and Theory 2, 105-200.

Catling, H. (1997) 'Heroes returned? Subminoan burials from Crete', in J. B. Carter and S. P. Morris (eds.), The Ages of Homer: a tribute to Emily Townsend Vermeule, Austin, 123-36.

Caubet, A. and Pierrat-Bonnefois, G. (eds.) (2005) Faïences de l'antiquité: de l'Égypte à l'Iran, Paris.

Chapman, R. (1987) 'Mortuary practices: society, theory building and archaeology', in A. Boddington, A. N. Garland and R. C. Janaway (eds.), Death, decay, and reconstruction: approaches to archaeology and forensic science, Manchester and Wolfeboro, $\mathrm{NH}, \mathrm{I} 98-2 \mathrm{I} 3$.

(2013) 'Death, burial, and social representation', in S. Tarlow and L. N. Stutz (eds.), The Oxford handbook of the archaeology of death and burial, Oxford, 47-57.

Chapman, R. and Randsborg, K. (I98I) 'Approaches to the archaeology of death', in R. Chapman, I. Kinnes, K. Randsborg (eds.), The archaeology of death, Cambridge and New York, I-24.

Clerc, G. (I99I) 'Aegyptiaca', in V. Karageorghis, O. Picard and C. Tytgat (eds.), Études chypriotes XII: La nécropole d'Amathonte, tombes 110-385. Vol. v: Les figurines en terre cuite archaïques et classiques: les sculptures en pierre, Nicosia, I-50.

Clerc, G., Karageorghis, V., Lagarce, E. and Leclant, J. (1976) Fouilles de Kition II: Objets égyptiens et égyptisants, Nicosia.

Coldstream, J. N. (I986) 'Kition and Amathus: some reflections on their westward links during the Early Iron Age', in V. Karageorghis (ed.), Acts of the international archaeological symposium 'Cyprus between the Orient and the Occident', Nicosia, 8-14 September 1985, Nicosia, 32I-9.

(1998) 'The first exchanges between Euboeans and Phoenicians: who took the initiative?', in S. Gitin, A. Mazar and E. Stern (eds.), Mediterranean peoples in transition: thirteenth to early tenth centuries BCE, Jerusalem, 353-6o.

(2003) Geometric Greece 900-700 BC, 2nd edn, New York.

(2007) 'Foreigners at Lefkandi?', in A. Mazarakis Ainian (ed.), Oropos and Euboea in the Early Iron Age, Volos, 135-9.

(2008) 'Early Greek exports to Phoenicia and the East Mediterranean', in C. Doumet-Serhal (ed.), Networking patterns of the Bronze and Iron Age Levant: the Lebanon and its Mediterranean connections, Beirut, $167-88$.

Crielaard, J. P. (I993) 'The social organization of Euboean trade with the Eastern Mediterranean during the Ioth to 8th centuries BC', Pharos I, I39-46.

(1998) 'Surfing on the Mediterranean web: Cypriot long-distance communications during the eleventh and tenth centuries BC', in V. Karageorghis and N. Stampolidis (eds.), Proceedings of the international symposium 'Eastern Mediterranean: Cyprus-Dodecanese-Crete, 16th-6th cent. BC', Athens, I87-206.

(2006) 'Basileis at sea: elites and external contacts in the Euboean Gulf region from the end of the Bronze Age to the beginning of the Iron Age', in S. Deger-Jalkotzy and I. S. Lemos (eds.), Ancient Greece: from the Mycenaean palaces to the Age of Homer, Edinburgh, 27I-97.

Crielaard, J. P. and Driessen, J. (I994) 'The hero's home: some reflections on the building at Toumba, Lefkandi', Topoi 4, 25I-70.

Dakoronia, P., Deger-Jalkotzy, S. and Sakellariou, A. (1996) Kleinere Griechische Sammlungen: Die Siegel aus der Nekropole von Elatia-Alonaki (Corpus der Minoischen und Mykenischen Siegel 5, suppl. 2), Berlin.

David, N. and Kramer, C. (200I) Ethnoarchaeology in action, Cambridge and New York.

de Salvia, F. (1978) 'Un ruolo apotropaico dello scarabeo egizio nel contesto culturale greco-arcaico di Pithekoussai (Ischia)', in M. B. de Boer and T. A. Edridge (eds.), Hommages à Maarten J. Vermaseren 3, Leiden, I003-6r.

(1993) 'Appendice II: I reperti di tipo egiziano', in G. Buchner and D. Ridgway (eds.), Pithekoussai. Volume I: La Necropoli: Tombe 1-723 scavate dal 1952 al 1961, Rome, 76I-8II. 
Desborough, V. R., Nicholls, R. V. and Popham, M. (1970) 'A Euboean centaur', BSA 65, 2I-30.

Descoeudres, J.-P. (2008) 'Central Greece and the Greek colonisation movement', in G. R. Tsetskhladze (ed.), Greek colonisation: an account of Greek colonies and other settlements overseas. Volume II, Leiden, $289-382$.

Dickers, A. (200I) Die spätmykenischen Siegel aus weichem Stein: Untersuchungen zur spätbronzezeitlichen Glyptik auf dem griechischen Festland und in der Ägäis, Rahden.

Dixon, H. M. (2013) 'Phoenician mortuary practice in the Iron Age I-III (ca. I200-ca. 300 BCE) Levantine "Homeland"', PhD thesis, University of Michigan.

Dornan, J. L. (2002) 'Agency and archaeology: past, present, and future directions', Journal of Archaeological Method and Theory 9, 303-29.

Evely, D. (ed.) (2006) Lefkandi Iv: The Bronze Age, the Late Helladic IIIC settlement at Xeropolis (BSA Suppl. 39), London.

Faraone, C. A. (I99I) 'Binding and burying the forces of evil: the defensive use of "voodoo dolls" in ancient Greece', ClAnt Io, I65-220.

Finley, M. I. (2002 [1954]) The world of Odysseus, New York.

Fletcher, R. N. (2006) 'The cultural biography of a Phoenician mushroom-lipped jug', OJA 25, I73-94.

(20II) 'Greek-Levantine cultural exchange in Orientalising and Archaic pottery shapes', AWE Io, II-42.

(2012) 'Opening the Mediterranean: Assyria, the Levant and the transformation of the Early Iron Age trade', Antiquity 86, 21I-20.

Fogelin, L. (2007) 'The archaeology of religious ritual', Annual Review of Anthropology 36, 55-7I.

Foxhall, L. (I998) 'Cargoes of the heart's desire: the character of trade in the Archaic Mediterranean world', in N. Fisher and H. van Wees (eds.), Archaic Greece: new approaches and new evidence, London, 295-309.

Frankenstein, S. (1979) 'The Phoenicians in the far west: a function of Neo-Assyrian imperialism', in M. T. Larsen (ed.), Power and propaganda: a symposium on ancient empires, Copenhagen, 263-94.

Friedman, J. and Rowlands, M. J. (1977) 'Notes toward an epigenetic model of civilization', in id. (eds.), The Evolution of Social Systems, London, 20I-76.

Gamer-Wallert, I. (2004) 'The Scarabs', in M. E. Aubet (ed.), The Phoenician cemetery of Tyre Al-Bass: excavations, 1997-1999, Beirut, 397-413.

Gilboa, A., Sharon, I., Boaretto, E. (2008) 'Tel Dor and the chronology of Phoenician "pre-colonisation" stages', in C. Sagona (ed.), Beyond the homeland: markers in Phoenician chronology, Leuven, $\mathrm{II}_{3}-204$.

Goldstein, L. G. (I976) 'Spatial structure and social organization: regional manifestations of Mississippian society', $\mathrm{PhD}$ thesis, Northwestern University.

(I98I) 'One-dimensional archaeology and multi-dimensional people: spatial organization and mortuary analysis', in R. Chapman, I. Kinnes and K. Randsborg (eds.), The Archaeology of Death, Cambridge and New York, 53-70.

Gorton, A. F. (1996) Egyptian and Egyptianizing scarabs: a typology of steatite, faience and paste scarabs from Punic and other Mediterranean sites, Oxford.

Gosden, C. (I985) 'Gifts and kin in Early Iron Age Europe', Man 20, 475-93.

Gras, M., Rouillard, P. and Teixidor, J. (I99I) 'The Phoenicians and death', Berytus 39, 127-76.

Gunter, A. C. (2009) Greek art and the Orient, Cambridge and New York.

Helms, M. W. (I993) Craft and the kingly ideal, Austin.

Heymans, E. and van Wijngaarden, G. J. (20II) 'Low-value manufactured exotics in the eastern Mediterranean in the Late Bronze and Early Iron Ages', in A. Vianello (ed.), Exotic in the prehistoric Medterranean, Oxford and Oakville, 124-36.

Hodder, I. (1980) 'Social structure and cemeteries: a critical appraisal', in P. Rahtz, T. Dickinson and L. Watts (eds.), Anglo-Saxon cemeteries, 1979: the fourth Anglo-Saxon symposium at Oxford (BAR 82), Oxford, I6I-9.

Hoffman, G. L. (I997) Imports and immigrants: Near Eastern contacts with Iron Age Crete, Ann Arbor. 
(2005) 'Defining identities: Greek artistic interaction with the Near East', in C. E. Suter and C. Uehlinger (eds.), Crafts and images in contact: studies on eastern Mediterranean art of the first millennium BCE, Fribourg, 35I-89.

Hölbl, G. (1979) Beziehungen der ägyptischen Kultur zu Altitalien, 2 vols., Leiden.

(1983) 'Ägyptischer Einfluß in der griechischen Kleinkunst', ÖJh 54, I-I7.

(I987) 'Zur kulturellen Stellung der Aegyptiaca in der mykenischen und frühgriechischen Welt', in E. Thomas (ed.), Forschungen zur aegaeischen Vorgeschichte: Das Ende der mykenischen Welt, Cologne and Berlin, 123-42.

Iakovidis, S. (1980) Excavations of the necropolis at Perati (Occasional Paper 8, Institute of Archaeology, UCLA), Los Angeles.

Janes, S. (2010) 'Negotiating island interactions: Cyprus, the Aegean and the Levant in the Late Bronze to Early Iron Ages', in P. van Dommelen and A. B. Knapp (eds.), Material connections in the ancient Mediterranean: mobility, materiality and identity, New York, 127-46.

Jones, S. (1974) Men of influence in Nuristan: a study of social control and dispute settlement in Waigal Valley, Afghanistan, London and New York.

Karageorghis, V. (1983) Palaepaphos-Skales: an Iron Age cemetery in Cyprus, Constance.

(1998) “'Astarte” in Naxos?', in V. Karageorghis and N. Stampolidis (eds.), Proceedings of the international symposium 'Eastern Mediterranean: Cyprus-Dodecanese-Crete, 16th-6th cent. BC', Athens, I2I-6.

Karetsou, A. (2000) Kriti-Aigyptos: politismikoi desmoi trion chilietion, 2 vols., Athens.

Keel, O. (1995) Corpus der Stempelsiegel-Amulette aus Palästine/Israel: Von den Anfängen bis zur Perserzeit. Einleitung, Freiburg and Göttingen.

Kenzelmann Pfyffer, A., Theurillat, T. and Verdan, S. (2005) 'Graffiti d'époque géométrique provenant du sanctuaire d'Apollon Daphnéphoros à Erétrie', ZPE I5I, 5I-83.

Kotsonas, A. (2006) 'Wealth and status in Iron Age Knossos', OJA 25, I49-72.

Kourou, N. (2003) 'Rhodes: the Phoenician issue revisited. Phoenicians at Vroulia?', in N. C. Stampolidis and V. Karageorghis (eds.), $\Pi \Lambda O E \Sigma \ldots$ sea routes ... interconnections in the Mediterranean, 16th-6th c. BC: proceedings of the international symposium held at Rethymnon, Crete, September 2gth-October 2nd, 2002, Athens, 249-62.

(2008a) 'The Aegean and the Levant in the Early Iron Age: recent developments', in A.-M. MaïlaAfeiche (ed.), Interconnections in the Eastern Mediterranean. Lebanon in the Bronze and Iron Ages: proceedings of the International Symposium, Beirut, $36 \mathrm{I}-73$.

(2008b) 'The evidence from the Aegean', in C. Sagona (ed.), Beyond the homeland: markers in Phoenician chronology, Leuven, 305-64.

(2012) 'Phoenicia, Cyprus and the Aegean in the Early Iron Age: J. N. Coldstream's contribution and the current state of research', in M. Iacovou (ed.), Cyprus and the Aegean in the Early Iron Age: the legacy of Nicolas Coldstream, Nicosia, 33-47.

Kramer-Hajos, M. (2009) 'Sailor-warriors and the end of the Bronze Age along the Euboean Gulf, Archaiologiko ergo Thessalias kai Stereas Helladas 3, 8II-2I.

Kroll, J. H. (2008) 'Early Iron Age balance weights at Lefkandi, Euboea', OJA 27, 37-48.

Krzyszkowska, O. (2005) Aegean seals: an introduction, London.

Kuhrt, A. (2002) 'Greek contact with the Levant and Mesopotamia in the first half of the first millennium BC: a view from the East', in G. R. Tsetskhladze and A. M. Snodgrass (eds.), Greek settlements in the Eastern Mediterranean and the Black Sea, Oxford, $17-25$.

Lemos, I. S. (200I) 'The Lefkandi connection: networking in the Aegean and the eastern Mediterranean', in L. Bonfante and V. Karageorghis (eds.), Italy and Cyprus in antiquity, 1500-400 BC, Nicosia, 215-26.

(2002) The Protogeometric Aegean: the archaeology of the late eleventh and tenth centuries BC, Oxford and New York.

(2003) 'Craftsmen, traders and some wives in Early Iron Age Greece', in N. C. Stampolidis and

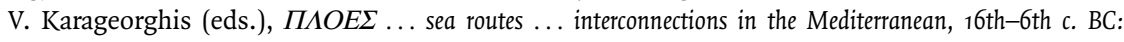


proceedings of the international symposium held at Rethymnon, Crete, September 29th-October 2nd, 2002, Athens, I87-95.

(2005) 'The changing relationship of the Euboeans and the East', in A. Villing (ed.), The Greeks in the East, London, 53-6o.

(2007) 'Recent archaeological work on Xeropolis, Lefkandi: a preliminary report', in A. Mazarakis Ainian (ed.), Oropos and Euboea in the Early Iron Age, Volos, I23-33.

(2012) 'Euboea and Central Greece in the Post-Palatial and Early Greek periods', AR 58, 19-27.

Lemos, I. S. and Mitchell, D. (20II) 'Elite burials in Early Iron Age Aegean: some preliminary observations considering the spatial organization of the Toumba cemetery at Lefkandi', in A. Mazarakis Ainian (ed.), The 'Dark Ages' revisited: acts of an international symposium in memory of William D. E. Coulson. Volume II, Volos, 635-44.

Malkin, I. (20II) A small Greek world: networks in the ancient Mediterranean, New York.

Mazar, E. (2004) 'The Phoenician family tomb N. I at the northern cemetery of Achziv (Ioth-6th centuries BCE)', Cuadernos de Arqueología Mediterránea Io, II-254.

Mazarakis Ainian, A. (I997) From rulers' dwellings to temples: architecture, religion and society in Early Iron Age Greece (1100-700 BC), Jonsered.

(2007-8) 'Buried among the living in Early Iron Age Greece: some thoughts', ScAnt I4.I, 365-98.

(2010) 'Tombes d'enfants à l'intérieur d'habitats au début de l'âge du fer dans le monde grec', in A.-

M. Guimier-Sorbets and Y. Morizot (eds.), L'enfant et la mort dans l'antiquité. Volume i: Nouvelles recherches dans les nécropoles grecques: le signalement des tombes d'enfants, Paris, 67-95.

(2012) 'The form and structure of Euboean society in the Early Iron Age based on some recent research', in Alle origini della Magna Grecia. Mobilità, migrazioni, fondazioni: atti del cinquantesimo convegno di studi sulla Magna Grecia, Taranto, 1-4 ottobre 2010, Taranto, 73-99.

Metcalf, P. and Huntington, R. (I99I) Celebrations of death: the anthropology of mortuary ritual, 2nd edn, Cambridge and New York.

Morris, I. (I987) Burial and ancient society: the rise of the Greek city-state, Cambridge and New York.

(2000) Archaeology as cultural history, Malden and Oxford.

Morris, S. P. (1992) Daidalos and the origins of Greek art, Princeton.

Morris, S. P. and Papadopoulos, J. K. (1998) 'Phoenicians and the Corinthian pottery industry', in R. Rolle and K. Schmidt (eds.), Archäologische Studien in Kontaktzonen der antiken Welt, Göttingen, $25 \mathrm{I}-64$.

Muhly, J. D. 2003. 'Greece and Anatolia in the Early Iron Age: the archaeological evidence and the literary tradition', in W. G. Dever and S. Gitin (eds.), Symbiosis, symbolism, and the power of the past: Canaan, ancient Israel, and their neighbors from the Late Bronze Age through Roman Palaestina, Winona Lake, IN, 23-35.

Niemeyer, H. G. (2003) 'On Phoenician art and its role in trans-Mediterranean interconnections ca. IIoo-6oo BC', in N. C. Stampolidis and V. Karageorghis (eds.), $\Pi \Lambda O E \Sigma ~ \ldots$ sea routes ... interconnections in the Mediterranean, 16 th-6th c. BC: proceedings of the international symposium held at Rethymnon, Crete, September 2gth-October 2nd, 2002, Athens, 20I-8.

Nightingale, G. (2007) 'Lefkandi: an important node in the international exchange network of jewellery and personal adornment', in I. Galanaki, H. Tomas, Y. Galanakis and R. Laffineur (eds.), Between the Aegean and Baltic areas. Prehistory across borders: proceedings of the international conference 'Bronze and Early Iron Age interconnections and contemporary developments between the Aegean and the regions of the Balkan Peninsula, Central and Northern Europe, University of Zagreb, 11-14 April 2005 (Aegaeum 27), 42I-9.

Nijboer, A. J. (2008) 'A Phoenician family tomb, Lefkandi, Huelva and the tenth century BC in the Mediterranean', in C. Sagona (ed.), Beyond the homeland: markers in Phoenician chronology, Leuven, $365-77$.

Nunn, A. (2004) 'Die Skarabäen und Skaraboide aus Westvorderasien und Mesopotamien', in A. Nunn and R. Schulz (eds.), Skarabäen außerhalb Ägyptens: Lokale Produktion oder Import? (BAR I205), I3-53. 
Panagiotopoulos, D. (2012) 'Encountering the foreign: (de-)constructing alterity in the archaeologies of the Bronze Age Mediterranean', in J. Maran and P. W. Stockhammer (eds.), Materiality and social practice: transformative capacities of intercultural encounters, Oxford and Oakville, 5I-60.

Papadopoulos, J. K. (I997) 'Phantom Euboians', JMA I0.2, I9I-2I9.

(20II) "Phantom Euboians" - a decade on', in D. W. Rupp and J. E. Tomlinson (eds.), Euboea and Athens: proceedings of a colloquium in memory of Malcolm B. Wallace, Athens, 26-27 June 2009, Athens, II3-34.

Papadopoulos, J. K. and Urton, G. (eds.) (2012) The construction of value in the ancient world, Los Angeles. Pare, C. F. E. (1992) Wagons and wagon-graves of the Early Iron Age in Central Europe, Oxford.

Parker, V. (I997) Untersuchungen zum Lelantischen Krieg und verwandten Problemen der frühgriechischen Geschichte (Historia 109), Stuttgart.

Parker Pearson, M. (I982) 'Mortuary practices, society and ideology: an ethnoarchaeological study', in I. Hodder (ed.), Symbolic and structural archaeology, Cambridge and New York, 99-II3.

(1999) The archaeology of death and burial, College Station, TX.

Pendlebury, J. D. S. (1930) Aegyptiaca: a catalogue of Egyptian objects in the Aegean area, Cambridge.

Perreault, J. Y. (I993) 'Les emporia grecs du levant: mythe ou réalité?', in A. Bresson and P. Rouillard (eds.), L'Emporion, Paris, 59-83.

Popham, M. (1994) 'Precolonization: early Greek contact with the East', in G. R. Tsetskhladze and F. De Angelis (eds.), The archaeology of Greek colonisation: essays dedicated to Sir John Boardman, Oxford, II-34. Popham, M. R., Calligas, P. G. and Themelis, P. G. (eds.) (1993) Lefkandi II: the Protogeometric building at Toumba. Volume ii: The excavation of the building, its architecture and finds, (BSA Suppl. 23), London.

Popham, M. R. and Lemos, I. S. (I995) 'A Euboean warrior trader', OJA I4, I5I-7.

(1996) Lefkandi III: The Toumba cemetery. The excavations of 1981, 1984, 1986 and 1992-1994, Plates (BSA Suppl. 29), Athens.

Popham, M. R., Sackett, L. H. and Themelis, P. G. (eds.) (1979-80) Lefkandi I: the Iron Age settlement. The cemeteries (BSA Suppl. II), London.

Popham, M. R., Touloupa, E. and Sackett, L. H. (I982) 'Further excavation of the Toumba cemetery at Lefkandi, I98I', BSA 77, 213-48.

Porada, E. I983. 'Appendix III: cylinder and stamp seals from Palaepaphos-Skales', in Karageorghis (1983), 407-10.

Rakita, G. F. M. and Buikstra, J. E. (2005) 'Introduction', in G. F. M. Rakita, J. E. Buikstra, L. A. Beck and S. R. Williams (eds.), Interacting with the dead: perspectives on mortuary archaeology for the new millennium, Gainesville, I-II.

Ridgway, D. (I992) The first Western Greeks, Cambridge.

Sader, H. (1995) 'Nécropoles et tombes phéniciennes du Liban', Cuadernos de Arqueología Mediterránea I, I5-32.

(2014-15) 'Funerary practices in Iron Age Lebanon', Archaeology and History in the Lebanon, 40-I, I00-I7.

Sahlins, M. D. (1963) 'Poor man, rich man, big-man, chief: political types in Melanesia and Polynesia', Comparative Studies in Society and History 5, 285-303.

Satlow, M. L. (2013) The gift in antiquity, Hoboken.

Saxe, A. A. (1970) 'Social dimensions of mortuary practices', $\mathrm{PhD}$ thesis, University of Michigan.

Shanks, M. and Tilley, C. (I982) 'Ideology, symbolic power and ritual communication', in I. Hodder (ed.), Symbolic and structural archaeology, Cambridge and New York, I29-54.

Shaw, J. W. and Shaw, M. C. (2000) Kommos Iv: the Greek sanctuary, Princeton.

Sherratt, S. (2008) 'Vitreous materials: questions of value', in C. M. Jackson and E. C. Wager (eds.), Vitreous materials in the Late Bronze Age Aegean, Oxford, 209-32.

(2010) 'Greeks and Phoenicians: perceptions of trade and traders in the early first millennium BC', in A. A. Bauer and A. S. Agbe-Davies (eds.), Social archaeologies of trade and exchange: exploring relationships among people, places, and things, Walnut Creek, CA, II9-42. 
Sherratt, S. and Sherratt, A. (1993) 'The growth of the Mediterranean economy in the early first millennium BC', WorldArch 24, 36I-78.

Skon-Jedele, N. J. (1994) 'Aigyptiaka: a catalogue of Egyptian and Egyptianizing objects excavated from Greek archaeological sites, ca. IIoo-525, with historical commentary', $\mathrm{PhD}$ thesis, University of Pennsylvania.

Smith, J. S. (2008) 'Cyprus, the Phoenicians and Kition', in C. Sagona (ed.), Beyond the homeland: markers in Phoenician chronology, Leuven, 26I-303.

(2009) Art and society in Cyprus from the Bronze Age into the Iron Age, New York.

Smithson, E. L. (I968) 'The tomb of a rich Athenian lady, ca. 850 BC', Hesperia 37, 77-II6.

Stampolidis, N. C. (1998) 'Imports and agalmata: the Eleftherna experience', in V. Karageorghis, N. Stampolidis (eds.), Proceedings of the international symposium 'Eastern Mediterranean: CyprusDodecanese-Crete 16th-6th cent. B.C.', Athens, $175-85$.

(2003) 'On the Phoenician presence in the Aegean', in N. C. Stampolidis, V. Karageorghis (eds.), $\Pi \Lambda O E \Sigma$... sea routes ... interconnections in the Mediterranean, 16th-6th c. BC. Proceedings of the international symposium held at Rethymnon, Crete, September 2gth-October 2nd, 2002, Athens, 217-32.

(ed.) (2004) Eleftherna: poli-akropoli-nekropoli, Athens.

Tainter, J. A. (1975) 'Social inference and mortuary practices: an experiment in numerical classification', WorldArch 7, I-I5.

(1978) 'Mortuary practices and the study of prehistoric social systems', in M. B. Schiffer (ed.), Advances in archaeological method and theory I, New York, I05-4I.

Ucko, P. (I969) 'Ethnography and archaeological interpretation of funerary remains', WorldArch I, 262-8I. van Wees, H. (1992) Status warriors: war, violence, and society in Homer and history, Amsterdam.

Vercoutter, J. (1945) Les objets égyptiens et égyptisants du mobilier funéraire carthaginois, Paris.

Walker, K. G. (2004) Archaic Eretria: a political and social history from the earliest times to $490 \mathrm{BC}$, New York.

Webb, V. (1978) Archaic Greek faience, Warminster, UK.

Wells, P. S. (I980) Culture contact and culture change: Early Iron Age Central Europe and the Mediterranean world, Cambridge and New York.

Whitley, J. (1991a) Style and society in Dark Age Greece: the changing face of a pre-literate society, 1100-700 BC, Cambridge and New York.

(I99Ib) 'Social diversity in Dark Age Greece', BSA 86, 34I-65.

Winter, I. J. (I995) 'Homer's Phoenicians: history, ethnography, or literary trope? (A perspective on early Orientalism)', in J. B. Carter, S. P. Morris (eds.), The Ages of Homer: a tribute to Emily Townsend Vermeule, Austin, 247-7I.

Yon, M. (I97I) Salamine de Chypre II: La tombe T.I. du xie s. av. J.-C., Paris. 